\title{
Unusual wound healing following suppurative BCG lymphadenitis
}

\author{
Yoshihiro Aoki, ${ }^{1,2}$ Katsuhiko Kitazawa, ${ }^{1}$ Shuichi Tanese ${ }^{1}$
}

'Department of Pediatrics, Asahi General Hospital, Asahi, Chiba, Japan

${ }^{2}$ Departmentof Intensive Care Medicine, Osaka Women's and Children's Hospital, Izumi, Osaka, Japan

Correspondence to Dr Yoshihiro Aoki, yaoki-hki@umin.ac.jp

Accepted 15 May 2018

\section{DESCRIPTION}

BCG lymphadenitis, a complication sometimes associated with BCG vaccination, usually resolves spontaneously without treatment. ${ }^{1}$ However, if suppurative BCG lymphadenitis develops, abscess formation and rupture can occur, leaving patients at risk for infections. Nevertheless, few studies have provided details on long-term wound-healing findings of patients following rupture.

We describe the case of an 8-month-old female infant who developed a left axillary mass following BCG vaccination. Medical examination revealed non-tender lymphadenopathy with swelling and erythema in her left axial area. We clinically diagnosed BCG lymphadenitis, and she was followed up without any specific medication. Nine months postvaccination, the mass spontaneously ruptured with residual necrotic material (figure 1A), which was removed by a plastic surgeon through a skin incision (figure $1 \mathrm{~B}$ ). The necrotic material was found to be contaminated by Mycobacterium bovis BCG str Tokyo 172, which was identified using a PCR test and sequence analysis. The examinations for immunodeficiency, including continuous granulomatosis, were negative. The wound closed naturally but subsequently developed irregular wart-like acrochordons (figure 1C). The

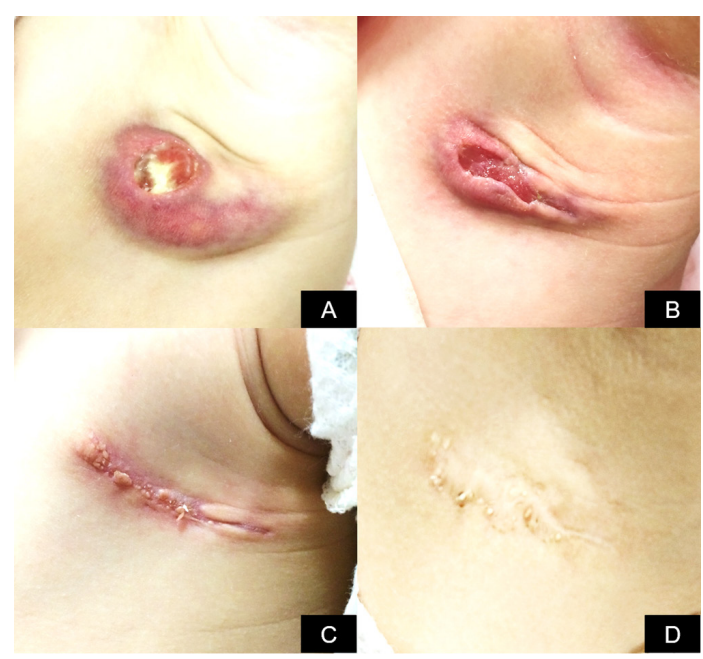

Figure 1 (A) Left axillary lymph node showing necrotic material after rupture. (B) Appearance of the left axillary lesion after a necrotomy through a partial skin incision. (C) Appearance of the wound 3 months after debridement. The wound is observed to have closed naturally but now shows the development of irregular wart-like acrochordons. (D) Appearance of the wound 2 years after debridement. The wart-like scar gradually resolved.

\section{Learning points}

- The healing process associated with BCG lymphadenitis might be accompanied by the development of unusual wart-like acrochordons.

- To prevent the development of irregular scarring or keloids, an aspiration procedure should be performed in suppurative BCG lymphadenitis before rupture.

- With appropriate debridement after rupture, the wounds associated with suppurative lymphadenitis can be cured without medication.

wart-like scar gradually resolved over a 2-year period with non-pharmacological therapy (figure 1D).

It has been suggested that surgical incision and drainage for suppurative BCG lymphadenitis could cause significant irregular scarring or keloids over the scar on healing. ${ }^{2}$ Therefore, in this case, the patient should have undergone needle aspiration earlier. ${ }^{1}$ This case suggests that the healing process associated with BCG lymphadenitis might be accompanied by the development of strange wart-like acrochordons that can develop over a longer recovery period, which is different from usual paediatric suppurative lymphadenitis. ${ }^{3}$ Moreover, in case of a rupture, conservative treatment remains a clinically relevant alternative in suppurative BCG lymphadenitis.

Acknowledgements The authors would like to thank N. Ishiwada and M. Ohkusu for PCR test and sequence analysis in diagnosis.

Contributors YA managed the patient, drafted the initial manuscript and approved the final manuscript prior to submission. KK critically reviewed and revised the manuscript, and approved the final manuscript prior to submission. ST managed the patient, reviewed and revised the manuscript, and approved the final manuscript prior to submission.

Funding The authors have not declared a specific grant for this research from any funding agency in the public, commercial or not-for-profit sectors.

Competing interests None declared.

Patient consent Parental/guardian consent obtained.

Provenance and peer review Not commissioned; externally peer reviewed.

(C) BMJ Publishing Group Ltd (unless otherwise stated in the text of the article) 2018. All rights reserved. No commercial use is permitted unless otherwise expressly granted.

\section{REFERENCES}

1 Riordan A, Cole T, Broomfield C. Fifteen-minute consultation: bacillus calmette-guérin abscess and lymphadenitis. Arch Dis Child Educ Pract Ed 2014;99:87-9.

2 Chan WM, Kwan YW, Leung CW. Management of bacille calmetteguerin lymphadenitis. HK J Paediatr 2011;16:85-94.

3 Luu TM, Chevalier I, Gauthier M, et al. Acute adenitis in children: clinical course and factors predictive of surgical drainage. J Paediatr Child Health 2005;41:273-7. 
Copyright 2018 BMJ Publishing Group. All rights reserved. For permission to reuse any of this content visit http://group.bmj.com/group/rights-licensing/permissions.

BMJ Case Report Fellows may re-use this article for personal use and teaching without any further permission.

Become a Fellow of BMJ Case Reports today and you can:

- Submit as many cases as you like

- Enjoy fast sympathetic peer review and rapid publication of accepted articles

Access all the published articles

- Re-use any of the published material for personal use and teaching without further permission

For information on Institutional Fellowships contact consortiasales@bmjgroup.com

Visit casereports.bmj.com for more articles like this and to become a Fellow 